\title{
Morphometric Analysis of Kito and Awetu Sub Basins Jimma, Ethiopia
}

\author{
Fayera Gudu Tufa ${ }^{*}$, Tolera Abdissa Feyissa \\ Hydraulic and Water Resources Engineering, Civil and Environmental Engineering, Jimma Institute of Technology, Jimma University, \\ Jimma, Ethiopia
}

\author{
Email address: \\ Fayerag2@gmail.com (F. G. Tufa), toleraabdissa@yahoo.com (T. A. Feyissa) \\ ${ }^{*}$ Corresponding author
}

\section{To cite this article:}

Fayera Gudu Tufa, Tolera Abdissa Feyissa. Morphometric Analysis of Kito and Awetu Sub Basins Jimma, Ethiopia. American Journal of Water Science and Engineering. Vol. 4, No. 3, 2018, pp. 80-90. doi: 10.11648/j.ajwse.20180403.14

Received: September 10, 2018; Accepted: October 22, 2018; Published: November 14, 2018

\begin{abstract}
Morphometric analysis is very important to evaluate watershed characteristics. Watershed characteristics are essential in watershed management, site selection for water resource projects, groundwater evaluation and proposing flood control measures. The present study aimed the morphometric analysis of Kito and Awetu sub-basins which drain into Kito and Awetu Rivers. Both rivers merge into a single river in Jimma town which is subjected to flood and sediment generated from both sub-basins. Topographic map of scale 1:50,000 was obtained from Ethiopian National Mapping Agency and satellite image of digital elevation model of fine resolution $(12.5 \mathrm{~m} \times 12.5 \mathrm{~m})$ was downloaded and used for morphometric analysis. GIS and remote sensing technique have been employed to generate and quantify morphometric parameters. Twenty-six parameters under linear aspects, areal aspects, and relief aspects were evaluated to characterize both Kito and Awetu sub-basins. Kito and Awetu Sub basins have both $5^{\text {th }}$ order stream and the $1^{\text {st }}$ order encompasses $78 \%$ and $77 \%$ of total stream number respectively which indicates the presence of flashy flood. The drainage area, basin perimeter, stream length and weighted mean bifurcation is $113.21 \mathrm{~km}^{2}, 82.65 \mathrm{~km}, 270.33 \mathrm{~km}$, and 4.51 respectively for Kito sub-basin and $77.17 \mathrm{~km}^{2}, 73.58 \mathrm{~km}, 192.45 \mathrm{~km}$, and 4.45 respectively for Awetu sub-basin. The values indicate that both sub-basins are characterized by mountainous, steep slope and mostly homogeneous geologic materials. The elongation ratio of Kito and Awetu sub-basins are 0.62 and 0.64 respectively. Kito and Awetu sub-basins are both elongated and the rivers have slow hydrograph for a long time. Relatively, Awetu sub-basin is more elongated than Kito sub-basin. The study reveals that both sub-basins are susceptible to surface runoff and soil erosion but the rivers are long and easy to manage flood occurrence.
\end{abstract}

Keywords: Awetu Sub Basin, GIS, Kito Sub Basin, Morphometric Analysis, Remote Sensing

\section{Introduction}

A drainage basin is a land area drained by a stream and its tributaries having a common outlet for surface runoff. Studying drainage basin is vital for the better understanding of the hydrological processes [1]. Hydrological processes like runoff, soil erosion, and sediment transports are highly influenced by morphometric characteristics of the drainage basin. Thus, morphometric analysis of a drainage basin is considered to be the most appropriate method for the proper planning and management of the watershed. It will give understanding the relationship among different aspects of the drainage pattern of the basin, and also make a comparative evaluation of different drainage basins, developed in various geologic and climatic regimes [2, 3].

Morphometric studies involve evaluation of the hydrogeological property, landform process, runoff and erosion characteristics of the drainage basin through measurement and mathematical analysis of morphometric parameters of drainage basin [4]. To evaluate and prioritize the basin for soil and water conservation, quantitative analysis of morphometric characteristics is of immense importance. Morphometric analysis of a watershed provides a quantitative description of the drainage system which is an important aspect of the characterization of watersheds.

Most researchers categorized morphometric parameters as linear, areal and relief aspects [5-8]. Some scholars classified morphometric parameters as drainage network, drainage 
texture and relief $[9,10]$ and others classified as basic, linear and shape parameters [11]. In those cases, the ultimate goal is to evaluate the characteristics of the drainage basin in response to hydrological phenomena.

Soil erosion leads to sedimentation, sedimentation leads to a morphological change of river channel which in turns leads to overflowing of the river which results to flooding. Jimma town is being threatened by such problems. Therefore, morphometric analysis of Kito and Awetu sub-basins is of prime importance to prioritize the sub-basins for watershed management practices.

Different methods have been developed for morphometric analysis and applied in many river basins and sub-basins in different parts of the globe [4, 12-18]. Various scholars have carried out morphometric analysis of river basins by using RS and GIS techniques [19-22]. GIS and remote sensing techniques are efficient tools in analyzing morphometric characteristics of the drainage basin. Waikar and Nilawar studied morphometric analysis of semi-arid agricultural watershed (Zerqa River Watershed), Northern Jordan for prioritization by using GIS and remote sensing techniques [23]. Gebre used GIS and remote sensing technique for analysis of Chelekot micro-watershed attributes, Northern Ethiopia for water resource management [24]. Fenta studied quantitative analysis and implications of drainage morphometry in Agula watershed, Ethiopia [20]. Panhalkar used GIS and remote sensing to study morphometric analysis and watershed development prioritization in Hiranyakeshi basin, Maharashtra, India [25]. Ratnam studied check dam positioning by prioritization of micro-watersheds using the sediment yield index (SYI) model and morphometric analysis in GIS environment [26]. The tool is proved to be efficient and most widely used in morphometric analysis and prioritizing watershed for best watershed management practices. Morphometric analysis of a watershed provides a quantitative description of a drainage system. It is an important aspect of the watershed characterization to propose effective watershed management practices.

Kito and Awetu drainage basins drain into Kito and Awetu Rivers respectively and their confluence is in Jimma town which is located in the southwestern part of Ethiopia. Flooding and morphological change of these Rivers are becoming a serious threat to the town since recent decades. Mainly Awetu River is becoming a serious threat to the lives and properties of people living along the River. Therefore, morphometric analysis of Kito and Awetu sub-basins is of prime importance to propose proper planning and management of the two sub-basins to control flooding and sedimentation in the rivers. The present study applied GIS and remote sensing to analyze morphometric characteristics of Kito and Awetu sub-basins.

\section{Description of the Study Area}

The study area, Kito and Awetu sub-basins are located in Southwestern part of Ethiopia; in Jimma Zone, Oromia Regional State. Both sub-basins are geographically laid between $7^{\circ} 38^{\prime} 00^{\prime} \mathrm{N}$ and $7^{\circ} 48^{\prime} 00^{\prime \prime} \mathrm{N}$ latitude and $36^{\circ} 40^{\prime} 00^{\prime \prime} \mathrm{E}$ and $36^{\circ} 56^{\prime} 00^{\prime \prime} \mathrm{E}$ longitude. Both sub-basins are found in the Northeastern part of Omo-Gibe River basin as shown in (Figure 1).

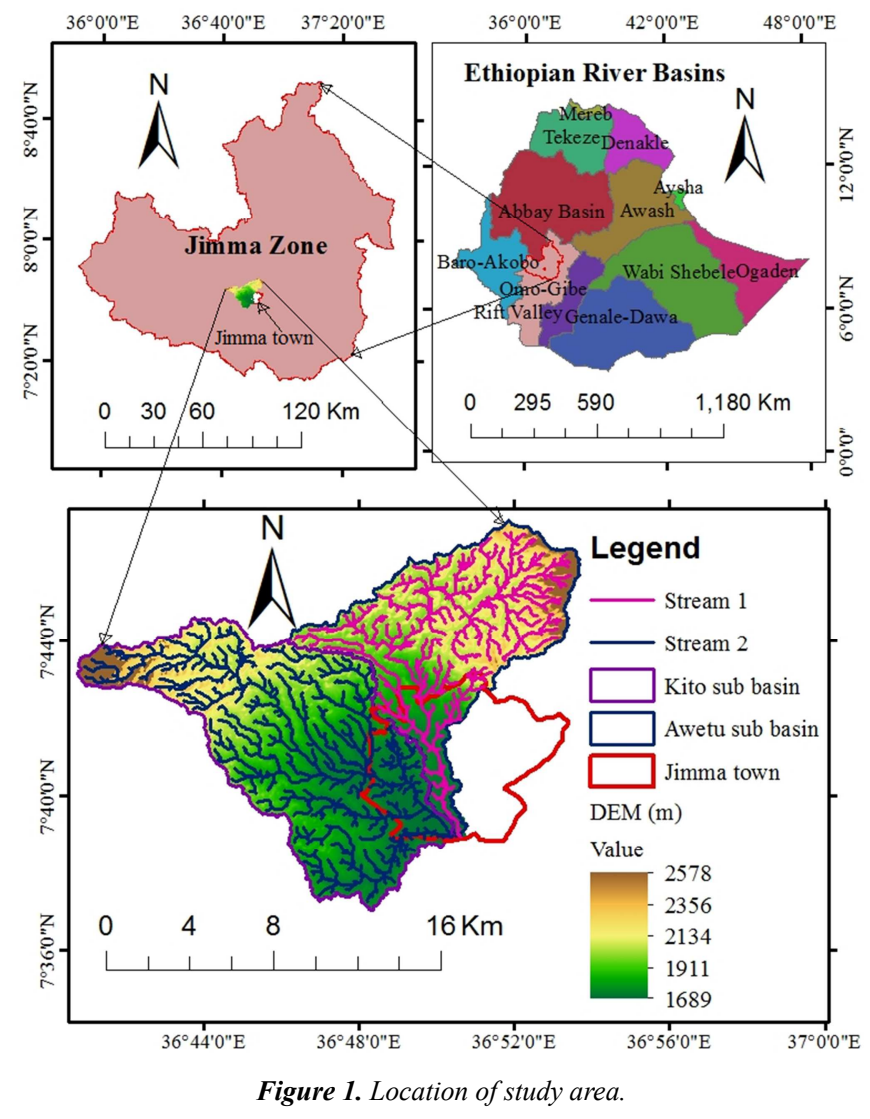




\section{Research Methodology}

\subsection{Data Collection and Processing}

In the present study, topographic map and remote sensing data (digital elevation model) have been used to analyze morphometric characteristics the Kito and Awetu sub-basins. Topographic map of scale 1:50,000 of the study area was obtained from Ethiopian National Mapping Agency (ENMA). The map was scanned and referenced to the Universal Transverse Mercator (UTM) map projection, Zone $37^{\circ} \mathrm{N}$. The stream networks were digitalized from the topographic map and used to recondition the digital elevation model (DEM). Digital elevation model (DEM) with spatial resolution $(12.5 \mathrm{mx} 12.5 \mathrm{~m}) \quad$ was downloaded from (https://vertex.daac.asf.alaska.edu), TM satellite imaginary. The digital elevation model was downloaded in two bands and mosaicking was done in ArcGIS environment. The coordinate of the DEM was converted to WGS-1984, zone $37^{\circ} \mathrm{N}$ projection system using ArcGIS software. After necessary corrections have been done, the watershed was delineated and Kito and Awetu sub-basins were generated by using the ArcSWAT software. Then sub-basin wise morphometric analysis was carried out with ArcGIS 10.1.

Steam network construction and stream ordering are prime steps in morphometric analysis and have been done by using ArcGIS software. Stream ordering of both sub-basins was ranked according to Strahler's method of the hierarchical ranking system [27]. The morphometric properties (basic, linear, and shape parameters) of both Kito and Awetu sub-basins were derived and calculated using GIS software. The overall process is described in (Figure 2).

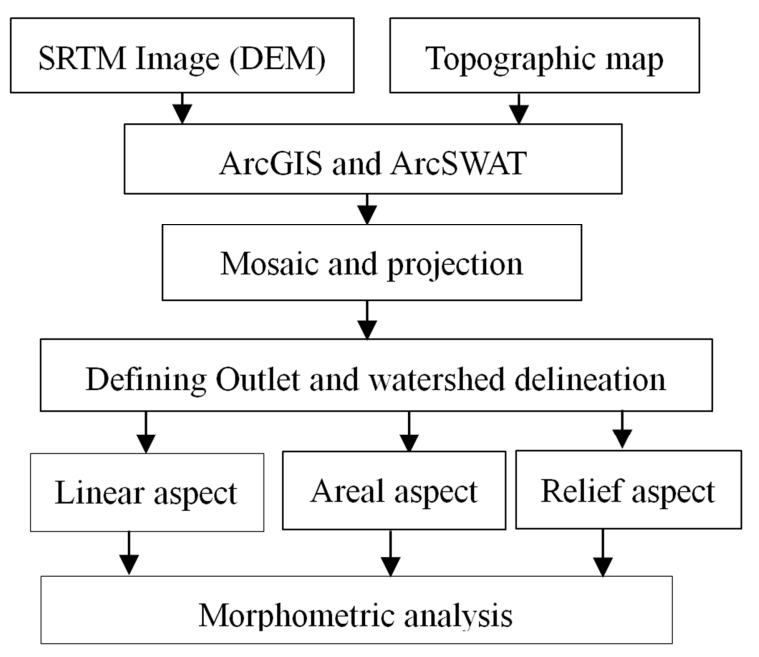

Figure 2. Workflow chart.

\subsection{Morphometric Analysis}

Morphometric analysis is very important for sustainable water conservation [28]. The term morphometry was derived from two Greek words 'morpho' which means an earth and metric which means measurement [5]. Morphometry can be defined as the measurement of earth features (topographic characteristics of the watershed). The morphometric analysis involves evaluation of watershed characteristics by measuring various steam properties [25]. Major Morphometric parameters (linear aspects, areal aspects, and relief aspects) which affect watershed characteristics were evaluated in a GIS environment. Morphometric parameters and respective methods used in the evaluation are described in (Table 1)

Table 1. Morphometric Parameters and computation methods.

\begin{tabular}{|c|c|c|c|}
\hline No & Morphometric Parameters & method/definition & source \\
\hline & Linear aspect & & \\
\hline 1 & Drainage basin area $(\mathrm{A}), \mathrm{Km}^{2}$ & The surface area of the watershed from ArcGIS & [13] \\
\hline 2 & Drainage basin parameter $(\mathrm{P}), \mathrm{Km}$ & Length of the boundary of the watershed & [13] \\
\hline 3 & Stream Order $(U)$ & Hierarchical Order (rank) & [4] \\
\hline 4 & Basin Length (Lb), Km & $1.312 \mathrm{~A}^{0.568}$, where $\mathrm{A}=$ Area of the drainage basin $(\mathrm{Km})$ & [16] \\
\hline 4 & Stream Length $(\mathrm{Lu}), \mathrm{Km}$ & Length of the Stream $(\mathrm{Km})$ & [13] \\
\hline 5 & Mean Stream Length (Lsm), Km & $\begin{array}{l}\mathrm{Lsm}=\mathrm{Lu} / \mathrm{Nu} \text { where, } \mathrm{Lu}=\text { total stream length of order ' } \mathrm{U} \text { ', } \\
\mathrm{Nu}=\text { stream length of the next higher stream order }\end{array}$ & {$[13]$} \\
\hline 6 & Stream length ratio $(\mathrm{RI})$ & $\begin{array}{l}\mathrm{RI}=\mathrm{Lu} /(\mathrm{Lu}-1) \text { where, } \mathrm{Lu}=\text { Total number of stream segment of order ' } \mathrm{U} \text { ', } \\
\mathrm{Lu}-1=\text { Stream length of the next higher order }\end{array}$ & {$[13]$} \\
\hline 7 & Bifurcation Ratio $(\mathrm{Rb})$ & $\begin{array}{l}\mathrm{Rb}=\mathrm{Nu} /(\mathrm{Nu}+1) \text {, Where, } \mathrm{Nu}=\text { Total number of stream segments of order ' } \mathrm{U} \text { ', } \\
\mathrm{Nu}+1=\text { Number of segments of the next higher order. }\end{array}$ & {$[16]$} \\
\hline 8 & $\begin{array}{l}\text { Arial Aspect } \\
\text { Drainage density (Dd), } \mathrm{Km} / \mathrm{Km}^{2}\end{array}$ & $\mathrm{Lu} / \mathrm{A}$, where $\mathrm{Lu}=$ Total length of stream and $\mathrm{A}=$ Area of watershed & {$[13]$} \\
\hline 9 & Drainage texture (Dt), per Km & $\begin{array}{l}\mathrm{Dt}=\mathrm{Nu} / \mathrm{P}, \text { Where }, \mathrm{Nu}=\text { Total number of stream of all orders and } \\
\mathrm{P}=\text { Basin perimeter measured in } \mathrm{km}\end{array}$ & {$[13]$} \\
\hline 11 & Stream frequency $(\mathrm{Fs})$, per $\mathrm{Km}^{2}$ & Fs $=N / A$, Where, $N=$ Total number of stream and $A=$ Area of watershed & [13] \\
\hline 12 & Form Factor (Rf) & $\mathrm{Rf}=\mathrm{A} / \mathrm{Lb}^{2}$, Where, $\mathrm{A}=$ Area of the watershed and $\mathrm{Lb}=$ Maximum basin length & \\
\hline 13 & Circularity Ratio (Rc) & $\mathrm{Rc}=(4 \pi \mathrm{A}) / \mathrm{P}^{2}$, Where, $\mathrm{A}=$ Area of the Watershed and $\mathrm{P}=$ basin Perimeter & {$[15]$} \\
\hline 14 & Elongation Ratio (Re) & $(2 / \mathrm{Lb}) \times(\mathrm{A} / \pi)^{0.5}$, Where, $\mathrm{A}=$ Area of the Watershed, $\mathrm{Lb}=$ Maximum Basin length. & {$[16]$} \\
\hline 14 & Length of Over Land Flow (Lo), km & Lo $=1 /(2 \mathrm{Dd})$, Where, $\mathrm{Dd}=$ Drainage density & [13] \\
\hline 16 & Infiltration number (If) & If $=$ Fs $x$ Dd Where $=$ Drainage density $\left(\mathrm{km} / \mathrm{km}^{2}\right)$ and Fs $=$ Stream frequency & {$[12]$} \\
\hline 17 & $\begin{array}{l}\text { Constant channel maintenance (C), } \\
\mathrm{km}^{2} / \mathrm{km}\end{array}$ & $C=1 / \mathrm{Dd}$, Where, $\mathrm{Dd}=$ Drainage Density & {$[13]$} \\
\hline 18 & Compactness coefficient $(\mathrm{Cc})$ & $\mathrm{Cc}=(0.2821 \mathrm{P}) / \mathrm{A}^{0.5}$, Where $\mathrm{A}=$ Area of the basin $\left(\mathrm{km}^{2}\right)$ and $\mathrm{P}=$ Basin perimeter & {$[13]$} \\
\hline
\end{tabular}




\begin{tabular}{|c|c|c|c|}
\hline No & Morphometric Parameters & method/definition & source \\
\hline 19 & $\begin{array}{l}\text { Drainage pattern } \\
\text { Relief Aspects: }\end{array}$ & & \\
\hline 20 & Basin Relief(Bh) & $\mathrm{Bh}=\mathrm{H}-\mathrm{h}$, where $\mathrm{H}$ and $\mathrm{h}$ are the elevations of highest and lowest point of the watershed & [16] \\
\hline 21 & Relief Ratio (Rh) & $\mathrm{Rh}=\mathrm{Bh} / \mathrm{Lb}$, Where, $\mathrm{Bh}=$ Basin Relief, $\mathrm{Lb}=$ Basin length. & [16] \\
\hline 22 & Relative relief $(\mathrm{Rr})$ & Rhp $=H \times 100 / P$, Where $H=$ Maximum basin relief and $\mathrm{P}=$ basin perimeter & [14] \\
\hline 23 & Ruggedness number $(\mathrm{Rn})$ & $\mathrm{Rn}=\mathrm{Bh} \times \mathrm{Dd}$, Where, $\mathrm{Bh}=$ Basin Relief and Dd $=$ Drainage Density & [16] \\
\hline 24 & Dissection index (Dis) & Dis $=\mathrm{H} / \mathrm{Hmax}$, Where $\mathrm{H}=$ Basin Relief and Hmax $=$ Maximum relief & \\
\hline 25 & Basin Slope $(\mathrm{Sb})$ & ArcGIS analysis & \\
\hline
\end{tabular}

\section{Results and Discussions}

The present study focused on the evaluation of morphometric parameters of Kito and Awetu sub-basins. The values of 26 morphometric parameters of both sub-basins were evaluated by using methods and equations described in (Table 1). Authors have made discussion on each parameter and comparison has been made between the two sub-basins.

\subsection{Linear Aspects}

Linear aspects are measurements of the linear feature of the watershed [5]. Linear aspects of morphometric parameters used to evaluate morphometric characteristics of Kito and Awetu sub-basins are basin area (A), basin perimeter (P), stream order $(\mathrm{U})$, basin length $(\mathrm{Lb})$, stream length $(\mathrm{Lu})$, mean stream lengths (Lsm), stream length ratio and bifurcation ratio (Rb).

\subsubsection{Basin Area (A)}

Basin area (A) is the most significant parameter in morphometric analysis. The volume of water that can be generated from the drainage basin and form stream flow is directly related to the drainage basin area [19]. Kito and Awetu sub-basins cover an area of $113.21 \mathrm{~km}^{2}$ and $77.17 \mathrm{~km}^{2}$ respectively.

\subsubsection{Basin Perimeter (P)}

Basin perimeter $(\mathrm{P})$ is the length of the water divide (demarcates) of the drainage basin. Basin perimeter determines the shape of the drainage basin. The shorter the basin perimeter, the circular the drainage basin will be and the longer the perimeter, the narrower and more elongated drainage basin. The basin perimeters of Kito and Awetu sub-basins are $82.65 \mathrm{Km}$ and $73.58 \mathrm{~km}$.

\subsubsection{Stream Order (U)}

Stream ordering is a foremost step in the morphometric analysis of drainage basin and there are various approaches to stream ordering [13, 18, 29, 30]. Strahler modified Horton method and its most widely used stream ordering system due to its simplicity. In the present study strahler's system has been used and the highest order is 5 for both Kito and Awetu sub-basins as described in (Table 6).

\subsubsection{Basin Length (Lb)}

Basin length (Lb) is described as the longest dimension of the basin in the direction of the main streamline [16]. Basin length is measured along the principal channel from the outlet to the water divide. Many researchers applied [16] formula to compute basin length [9-11, 19]. Basin length is an important parameter to compute other geometric (shape) parameters of the drainage basin. In the present study, Schumm's equation was used to determine the basin length (Table 1) of both Kito and Awetu sub-basins and their values are described in (Table 2) and (Table 3).

\subsubsection{Steam Length ( $\mathrm{Lu})$}

Stream length is the cumulative length of streams of all orders and thus the total channel length in the drainage basin for a given order [18]. Steam length is an important hydrological characteristic of the drainage basin and it shows surface runoff characteristics [9]. Stream length shows the landform evaluation, geological structure, and occurrence of floods. High stream length indicates the occurrence of high-intensity floods and runoff. In the present study, the total stream length of all stream orders was measured using ArcGIS tools and described in (Table 2) and (Table 3). The total stream lengths of Kito and Awetu sub-basins are $270.33 \mathrm{~km}$ and $92.45 \mathrm{~km}$ respectively. The stream with fairly smaller length is a characteristic of the basin with steep slopes and better textures. Rivers having longer lengths are commonly suggestive of smoother slope [10].

\subsubsection{Mean Stream Length (Lsm)}

Mean stream length (Lsm) is the ratio of total stream length of a given order, $\mathrm{U}$ to the total number of streams in the order [3]. The mean stream length of channel emphasizes the characteristic of drainage network and its contributing drainage basin surfaces [4]. Mean Stream Length increases from first order to higher order where stream length decreases from first order to higher order total. The mean stream length of Kito sub-basin is $4.47 \mathrm{~km}$ and that of Awetu sub-basin is $4.62 \mathrm{~km}$. Mean stream length for each order for both Kito and Awetu sub-basins are described in (table 2) and (Table 3).

\subsubsection{Stream Length Ratio (Lur)}

Stream length ratio (Lur) is defined as the ratio of the mean stream length (Lsm) of a given order (U) to the mean stream length (Lsm) of the next lower order [13]. Stream length ratio tends to be constant throughout the successive orders of a drainage basin [13]. The mean stream lengths of each of the successive orders of the basin tend to approximate a direct geometric sequence in which the first term (stream length) is the average of the first order. The stream length ratios (Lur) of both sub-basins are increasing with stream order and presented in (Table 2) and (Table 3). Except for Awetu sub-basin Lur of the $4^{\text {th }}$ order is less than that of the $5^{\text {th }}$ order 
which reflects the heterogeneity of geological materials. Changes in stream length ratio from one order to the other order indicate their late youth stage of geomorphic development. The weighted mean stream length ratio (Luwm) of the sub-basins are determined by dividing the total sum of the products of Lur and Lur-r by the total sum of Lur-r (Table 2) and (Table 3). The Luwm of Kito and Awetu sub-basins are found to be 2.45 and 2.85 respectively.

Table 2. Mean stream length and stream length ratio of Kito sub-basin.

\begin{tabular}{lllllll}
\hline $\mathbf{U}$ & Nu & Lu & Lsm & Lur & Lur-r & Lur*Lur-r \\
\hline 1 & 341 & 131 & 0.38 & & & \\
2 & 73 & 64.4 & 0.88 & 2.30 & 195.31 & 449.05 \\
3 & 18 & 39.7 & 2.21 & 2.50 & 104.14 & 260.42 \\
4 & 6 & 19.7 & 3.28 & 1.49 & 59.42 & 88.38 \\
5 & 1 & 15.6 & 15.6 & 4.76 & 35.30 & 167.88 \\
Total & 439 & 270.33 & & & 394.17 & 965.72 \\
\hline
\end{tabular}

Table 3. Mean stream length and stream length ratio of Awetu sub-basin.

\begin{tabular}{llllllll}
\hline $\mathbf{U}$ & Nu & Lu & Lsm & Lur & Lur-r & Lur*Lur-r \\
\hline 1 & 261 & 94.2 & 0.36 & & & \\
2 & 57 & 45.3 & 1.22 & 3.39 & 139.50 & 472.66 \\
3 & 15 & 29.6 & 1.97 & 1.61 & 74.87 & 120.78 \\
4 & 3 & 5.07 & 1.69 & 0.86 & 34.68 & 29.71 \\
5 & 1 & 18.3 & 18.3 & 10.81 & 23.35 & 252.38 \\
Total & 316 & 192.45 & & & 272.39 & 875.53 \\
\hline
\end{tabular}

$\mathrm{U}=$ stream order, $\mathrm{Lu}=$ sream length, $\mathrm{Lsm}=$ mean stream length, Lur $=$ stream length ratio, Lu- $\mathrm{r}=$ stream length used in the ratio and Luwm $=$ weighted mean stream length ratio

\subsubsection{Bifurcation Ratio (Rb)}

Bifurcation ratio $(\mathrm{Rb})$ is the ratio of the number of streams of a given order to the number of streams of the next higher order. This ratio can be expressed as [13]. The value of the bifurcation ratio reflects the relief and dissection of the drainage basin. The value of bifurcation ratio varies from 2 in flat or rolling drainage basin to 6 in mountain or hilly drainage basin where drainage network is highly distorted [19]. The hydrological response of drainage basin to rainfall is highly correlated with bifurcation ratio. High value of bifurcation ratio denotes high surface runoff and early hydrographic peak with a high potential of susceptibility to flash flooding during intense rainfall storm [11]. Surface runoff is highly correlated with soil erosion and thus, high surface runoff reflects the vulnerability of the basin to soil erosion.

The weighted mean bifurcation ratio was computed by multiplying bifurcation ratio for each successive pair of orders by the total number of orders involved in the ratio and taking the mean of the sum of these values [31]. Weighted mean bifurcation ratio of Kito and Awetu sub-basins are 4.51 and 4.45 respectively. This implies that both sub-basins are sensitive to runoff and soil erosion. As Rb gets higher the flow energy gets lower and the flow gets sufficient time for infiltration and recharges groundwater [4].

Table 4. Weighted mean bifurcation ratio of Kito sub-basin.

\begin{tabular}{lllll}
\hline $\mathbf{U}$ & $\mathbf{N u}$ & $\mathbf{R b}$ & $\mathbf{N u}-\mathbf{r}$ & $\mathbf{R b}$ Nu-r \\
\hline 1 & 341 & & & 1933.89 \\
2 & 73 & 4.67 & 414 & 369.06 \\
3 & 18 & 4.06 & 91 & 72.00 \\
4 & 6 & 3.00 & 24 & 42.00 \\
5 & 1 & 6.00 & 7 & 2416.946 \\
Total & 439 & & 536 & 2.51 \\
\hline
\end{tabular}

Table 5. Weighted mean bifurcation ratio of Awetu sub-basin.

\begin{tabular}{lllll}
\hline $\mathbf{U}$ & $\mathbf{N u}$ & $\mathbf{R b}$ & $\mathbf{N u}-\mathbf{r}$ & $\mathbf{R b} \mathbf{N u - r}$ \\
\hline 1 & 261 & & & \\
2 & 37 & 7.05 & 298 & 2102.11 \\
3 & 15 & 2.47 & 52 & 128.27 \\
4 & 3 & 5.00 & 18 & 90.00 \\
5 & 1 & 3.00 & 472.00 & 12 \\
Total & 317 & & 372 & 2332.37 \\
\hline
\end{tabular}

$\mathrm{U}=$ stream order, $\mathrm{Nu}=$ stream number, $\mathrm{Rb}=$ bifurcation ratio, $\mathrm{Nu}-\mathrm{r}=$ number of stream used in the ratio and $\mathrm{Rbwm}=$ weighted mean bifurcation ratio. 


\subsection{Areal Aspects}

Areal aspects $(\mathrm{Au})$ of a watershed of given order $(\mathrm{U})$ is defined as the total area projected upon a horizontal plane contributing overland flow to the channel segment of the given order and includes all tributaries of lower order [5]. Areal aspect morphometric parameters evaluated in the present study are drainage density $\left(D_{d}\right)$, drainage texture $(D t)$, Textural ratio $(\mathrm{T})$, stream frequency $(\mathrm{Fs})$, form factor (Rf), circulatory ratio $(\mathrm{Rc})$, elongation ratio $(\mathrm{Re})$, length of overland flow (Lof), infiltration number (If), constant of channel maintenance $(\mathrm{C})$ and compactness coefficient $(\mathrm{Cc})$.

\subsubsection{Drainage Density (Dd)}

Drainage density (Dd) is the ratio of total length of the streams of all orders per unit area of the drainage basin. It emphasizes the closeness of stream channels in the drainage basin. Drainage basin with high Dd is characterized by highly impermeable subsoil material, sparse vegetation cover, high relief high runoff, and low infiltration capacity. In other words, drainage basin with low $\mathrm{Dd}$ is characterized by highly permeable subsoil material, dense vegetation cover, low relief, low runoff, and high infiltration capacity. It reflects the terrain dissection and runoff potential of the drainage basin [19]. High drainage density reflects the presence of high steam channel concentration and therefore, relatively high runoff and low infiltration rate. Drainage density can be classified as very coarse $(<2)$, coarse $(2-4)$, moderate (4-6), fine (6-8) and very fine $(>8)$ [32]. The overall drainage density of Kito and Awetu sub-basins are 2.34 and $2.49 \mathrm{Km} / \mathrm{Km}^{2}$ respectively. This shows that the drainage densities of the basins are coarse.

The drainage density of whole sub-basins was classified by using ArcGIS as described in (Figure 3). Both Kito and Awetu sub-basins exhibit similar characteristics.

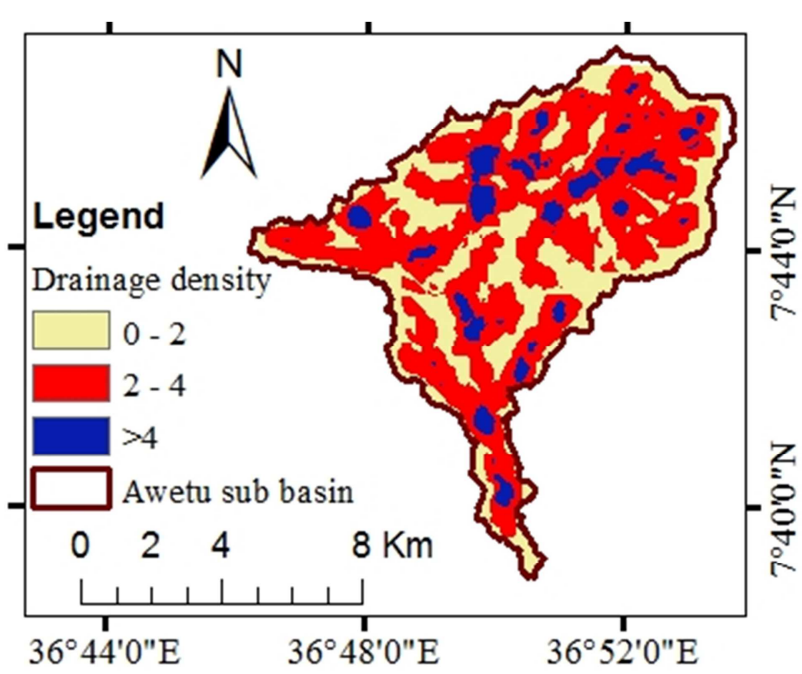

Figure 3. Drainage density map of Kito and Awetu sub-basins.

\subsubsection{Drainage Texture (Dt) and Textural Ratio (T)}

Drainage texture is the ratio of the total number of stream segments of all orders to the total perimeter of the drainage basin [13]. Drainage texture can be affected by the underlying lithology, climate, rainfall, infiltration capacity, developmental stage and relief aspect of the terrain. It is an important parameter to understand the geomorphology of the drainage basin $[6,8,9,19,21]$. Drainage texture is classified into five classes, very coarse $(<2)$, coarse $(2-4)$, moderate $(4$ $-6)$, fine $(6-8)$ and very fine $(>8)$ [21]. The drainage texture of Kito sub-basin is 5.31 per $\mathrm{Km}$ and 4.58 per $\mathrm{Km}$ for Awetu sub-basin. Drainage texture of both Kito and Awetu Sub basins can be classified as moderate texture. But relatively Dt of Awetu sub-basin is coarser than that of Kito sub-basin.

Textural ratio $(\mathrm{T})$ can be expressed as the ratio of the total number of first order stream $(\mathrm{Nu})$ to the total perimeter of the drainage basin $(\mathrm{P})$ [16]. Like drainage texture (Dt) it depends on the underlying lithology, infiltration capacity and relief aspect of the terrain. Textural ratio of Zerqa River watershed was determined as 1.463 and concluded as high runoff condition [19]. The textural ratio of the present study was estimated to be 4.12 per $\mathrm{Km}$ for Kito sub-basin and 3.55 per $\mathrm{Km}$ for Awetu sub-basin (Table 6) and the values indicate that both Kito and Awetu sub-basins are characterized by high runoff condition [10,11, 21, 33].

\subsubsection{Stream Frequency (Fs)}

The stream frequency (Fs) is defined as the total number of stream segment of all order per unit area of drainage basin [25]. The stream frequency varies from basin to basin. The higher the value of stream frequency, the larger will be the number of stream availability. Water with higher stream frequency is characterized by high runoff. Fs of Kito and Awetu sub-basins are 3.88 and 4.37 per $\mathrm{km}^{2}$ respectively.

\subsubsection{Form Factor (Rf)}

Form factor (Rf) is defined as the ratio of drainage basin area to the square of the basin length. Form factor reflects the shape of the drainage basin form as a stretched ellipse. As Rf closer to 0 , the shape of the drainage basin become elongated and as $\mathrm{Rf}$ closer to 1 , the shape of the basin becoming circular in shape [4]. The range of form factor would be $<0.7854$ (for 
elongated basin) and $>0.78$ (for circular basin). The drainage basin with higher form factor is normally circular in shape and characterized by high peak flow for a shorter duration. The drainage basin with low form factor is more elongated in shape and characterized by low peak flow for a longer duration. The elongated drainage basin is easier to manage than the circular basin $[25,32,33]$. The value of form factor for Kito sub-basin is 0.30 and 0.32 for Awetu sub-basin. The results show both sub-basins are elongated in shape and thus, characterized by low peak flow for a longer duration.

\subsubsection{Circulatory Ratio (Rc) and Elongation Ratio (Re)}

Circulatory ratio $(\mathrm{Rc})$ is defined as the ratio of the area of drainage basin to the area of the circle having the same circumference as the perimeter of the drainage basin [15]. A high value of circulatory ratio reflects the existence of strong structural control on the drainage basin and low value reflects no structural disturbance in the watershed [32]. On the other hand, circulatory ratio increasing with decreasing stream order [19]. The circulatory ratio is unity when the shape of the drainage basin is a perfect circle. Miller argued that circulatory ratio is influenced by the length of streams, stream frequency, geological structures, relief, slope steepness, climate, and land use/land cover of the drainage basin [15]. According to Miller, drainage basins with a range of circularity ratios of up to 0.5 are strongly elongated [15]. In the present study, the circulatory ratio of Kito sub-basin is 0.21 and that of Awetu sub-basin is 0.18 which indicate that the drainage basins are strongly elongated which agreed with the result of form factor.

Elongation ratio $(\mathrm{Re})$ refers to the ratio of the diameter of a circle having the same area as the drainage basin to maximum basin length [3]. The value of elongation ratio ranges from 0.6 to 1 and varies with climate and geologic types. A higher value of the elongation ratio reflects the drainage basin has lower relief and vice versa. Low elongation ratio is associated with high relief and steep ground surface slope [4]. Based on the value of elongation ratio, drainage basin can be classified as circular $(>0.9)$, oval $(0.9-0.8)$, less elongated $(0.8-0.7)$, elongated $(0.7-0.5)$ and More elongated $(<0.5)$ [8]. The values of Re of the present study are 0.62 and 0.64 for Kito and Awetu sub-basins respectively. The values indicate that the sub-basins are elongated.

\subsubsection{Length of Overland Flow (Lo)}

Length of overland flow (Lo) refers to the length that water flows over the ground before it becomes concentrates into definite stream channels. Lo is half of the reciprocal of drainage density and higher value of the length of overland flow represents low relief whereas low value represents high relief [19]. A low value of the length of overland indicates steep surface slope and rainfall enters into the stream very quickly. Thus the basin is characterized by a low infiltration rate and high surface runoff. The length of overland flow for Kito and Awetu sub-basin are $0.21 \mathrm{~km}$ and $0.20 \mathrm{~km}$ respectively.

\subsubsection{Infiltration Number (If)}

Infiltration number (If) of a drainage basin is defined as the product of drainage density and stream frequency $[6,9,21]$.
Infiltration number reflects the infiltration characteristics of the drainage basin. Drainage basin with higher infiltration number is characterized by low infiltration and high runoff. Infiltration number of Baitarani basin [6] and Rajasthan watershed [9] were found to be 4.92 and 0.061 respectively. The infiltration number of Kito and Awetu sub-basins are found to be 9.26 and 10.89 respectively. The results revealed that both sub-basins are characterized by a low infiltration rate and high surface runoff.

\subsubsection{Constant of Channel Maintenance (C)}

Constant channel maintenance $(\mathrm{C})$ is a reciprocal of drainage density (Dd). It is a property of landforms that refers to the number of square kilometers of drainage basin surface required to develop and sustain a channel of $1 \mathrm{~km}$ long in the basin [16]. It indicates the relative size of landform in the drainage basin which has a specific connotation. The constant channel maintenance of the sub-basins are $0.42 \mathrm{~km}^{2} / \mathrm{km}$, $0.40 \mathrm{~km}^{2} / \mathrm{km}$ for Kito and Awetu respectively. The basin with higher $\mathrm{C}$ is characterized by low relief and vice versa.

\subsubsection{Compactness Coefficient (Cc)}

Compactness coefficient $(\mathrm{Cc})$ is defined as the ratio of the perimeter of the catchment to the perimeter of the circular area with the same area of the drainage basin. Compactness coefficient is highly influenced by slope steepness. A high value of compactness coefficient $(\mathrm{Cc}>1)$ reflects the drainage basin is deviated from circular nature and lower value of compactness coefficient reflects the drainage is elongated [11]. An elongated drainage basin is characterized by a slow concentration of discharge and circular drainage basin is characterized by a quick concentration of discharge. The compactness coefficients are 2.19 and 2.36 for Kito and Awetu sub-basins respectively.

\subsubsection{Drainage Pattern}

Drainage pattern is the drainage system formed by streams, rivers, and lakes in a particular drainage basin. Drainage pattern is governed by the topography of the land, lithology, structure, and the gradient of the land [5]. Drainage basin reflects characteristics of the drainage basins. Some of these characteristics are the geology of the basin, depositional rocks, the existence of faults and geological structures [10]. A drainage basin is described as accordant if its pattern correlates to the structure and relief of the landscape over which it flows.

Some of the drainage patterns are dendritic drainage pattern, radial drainage pattern, trellis drainage pattern, rectangular drainage pattern and parallel drainage pattern [5]. Dendritic drainage patterns are formed in $\mathrm{V}$-shaped valley following the slope of the terrain. Developed in drainage basin where geology of the area is rocky and impervious. A parallel drainage pattern is a system of streams caused by steep slopes with high relief. The streams are swift and straight with very few tributaries and all flow in parallel. Trellis drainage pattern formed when the stream flows along a strike valley and smaller tributaries feed into it from the steep slopes on the sides of mountains. These tributaries enter the main Stream at approximately 90-degree angles, causing a trellis-like appearance of the drainage system. Rectangular drainage 
pattern consists of straight line segments with right angle bends and tributaries join larger streams at right angles. It develops on rocks that are of approximately uniform resistance to erosion, but which have two directions of jointing at approximately right angles. In a radial drainage pattern, the streams radiate outwards from a central high point [5]. As described in (Figure 4) Kito sub-basin has a dendritic drainage

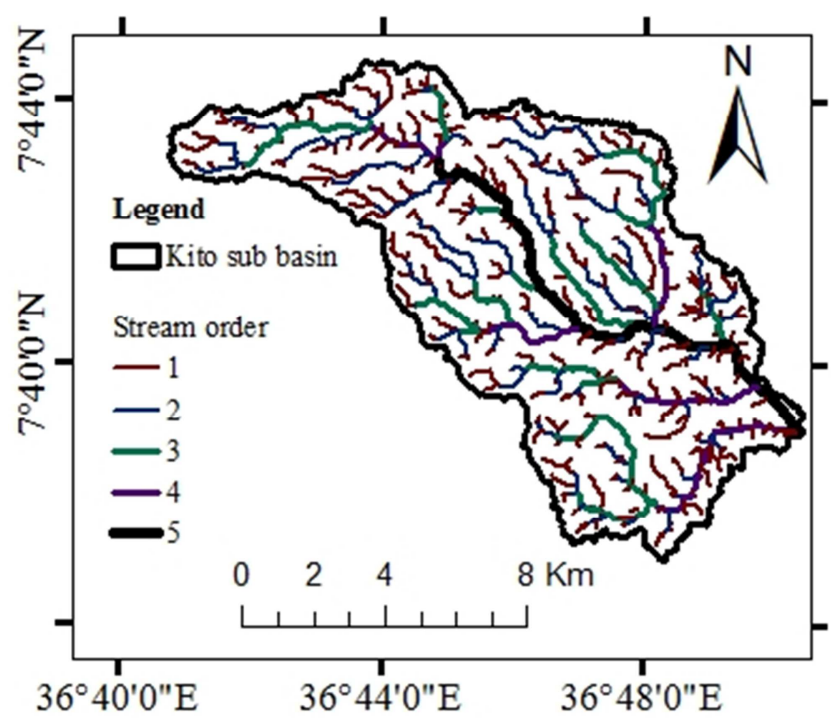

pattern whereas Awetu sub-basin has mostly dendritic and radial pattern on its southeastern part. This indicates that the underlain material of Kito sub-basin is homogeneous and there is uniform resistance to the runoff and erosion (weathering). For Awetu sub-basin, its drainage pattern is similar to that of Kito sub-basin but it reflects the presence of mountainous topography on its southeasternmost part.

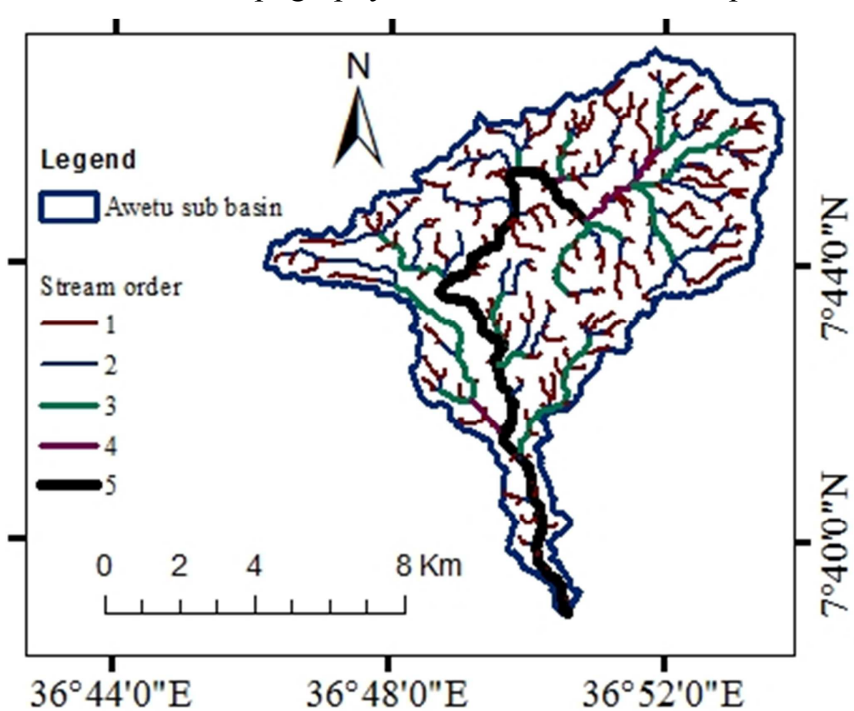

Figure 4. Drainage network of Kito and Awetu sub basins.

\subsection{Areal Aspects}

Relief aspects are an important factor in understanding the extent of denudation process undergone within the drainage basin and it is an indicator of the flow direction of the water. Relief aspects are basin relief $(\mathrm{H})$, relief ratio $(\mathrm{Rh})$, relative relief $(\mathrm{Rr})$, ruggedness number $(\mathrm{Rn})$, dissection index (Dis) and basin Slope $(\mathrm{Sb})$.

\subsubsection{Basin Relief $(\mathrm{H})$}

Watershed relief $(\mathrm{H})$ is defined as elevation difference between the remotest point and pour point in the drainage basin $[5,8]$. In the present study, the highest elevation at the remotest points (water divide) is $2459 \mathrm{~m}$ and $2578 \mathrm{~m}$ for Kito and Awetu sub-basins respectively. The lowest elevations at the outlets are $1690 \mathrm{~m}$ for both sub-basins. The overall reliefs of Kito and Awetu sub-basins are $0.77 \mathrm{~km}$ and $0.89 \mathrm{~km}$ respectively.

\subsubsection{Basin Relief (Rh)}

The relief ratio $(\mathrm{Rh})$ is defined as the ratio of total relief of the drainage basin to the maximum length of the drainage basin parallel to the main drainage channel [16]. Low relief ratio refers to a mild slope and high relief ratio refers to a steep slope region. However, there is no specified range to indicate the scale of severity. Relief ratio is highly correlated with the sensitivity of soil to erosion and high relief ratio indicates that the basin is prone to soil erosion $[5,9,10,32]$. The relief ratio of Kito and Awetu sub-basins are 0.04 and 0.06 respectively.

\subsubsection{Relative Relief ( $R r)$}

Relative relief is the ratio of maximum relief to the perimeter of the drainage basin $[5,9,10]$. The relative reliefs of sub-basins are 0.009 and 0.021 for Kito and Awetu respectively.

\subsubsection{Ruggedness Number (Rn)}

Ruggedness number $(\mathrm{Rn})$ is defined as the product of the basin relief and drainage density [4]. Ruggedness number reflects the structural complexity of the terrain in association with relief and drainage density [9]. The low ruggedness value of watershed implies that area is less prone to soil erosion and have intrinsic structural complexity in association with relief and drainage density [10]. The Ruggedness numbers of Kito and Awetu sub-basins are 1.84 and 2.21 respectively.

\subsubsection{Dissection Index (Dis)}

Dissection index (Dis) is the ratio of basin relief to the maximum (absolute relief) of the basin. Dissection index describes the degree of dissection or vertical erosion of land escape in a given physiographic region or drainage basin $[6,21$, 32]. The value of dissection index ranges from 0 and 1 . The lower value of dissection index indicates the flat and less vertical or slope landscape. The higher value of dissection index indicates vertical cliffs or hillslope [21]. Panda evaluated the dissection index of Baitarani basin as 0.998 that indicates the basin is highly dissected. The dissection indexes of both sub-basins are 0.31 and 0.34 for Kito and Awetu respectively [6].

\subsubsection{Basin Slope (Sb)}

The slope of the drainage basin has been generated by using Arc GIS 10.1, surface analysis tool as described in (Figure 5). Basin slope an important parameter which enables the assessment of runoff and soil erosion from a given drainage 
basin [6]. It is an important parameter which directly controls the balance between runoff response and soil infiltration rates of a terrain [24]. Gebre classified the slope map of the Chelekot micro-watershed into six classes in percent. $0 \%-3 \%$ (flat or almost flat), 3\% - 8\% (gentle slopping), $8 \%-15 \%$

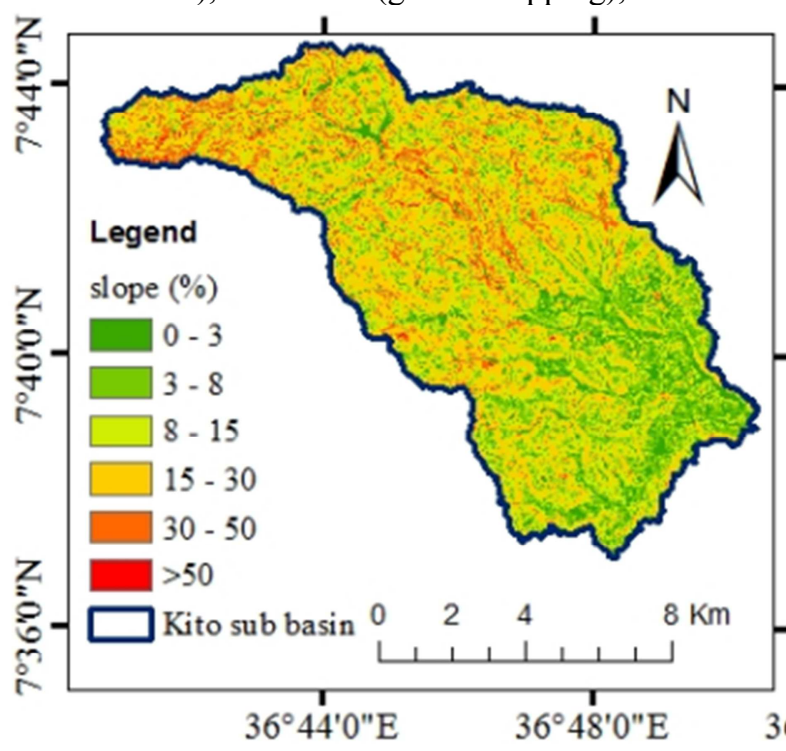

(sloping), 15\% - 30\% (moderately steep), 30\% - 50\% (steep) and $>50 \%$ (very steep) [24]. Slope map of the present study area for both Kito and Awetu sub-basins are shown in (Figure 5).

Figure 5. Map of slope classification of Kito and Awetu sub-basin.

Table 6. Values of morphometric parameters for Kito and Awetu sub-basins.

\begin{tabular}{|c|c|c|c|}
\hline No & Morphometric Parameters & Kito sub-basin & Awetu sub-basin \\
\hline & Linear aspect & & \\
\hline 1 & Drainage basin area (A) & 113.21 & 77.17 \\
\hline 2 & Drainage basin parameter $(\mathrm{P})$ & 82.65 & 73.58 \\
\hline 3 & Stream $\operatorname{Order}(\mathrm{U})$ & 5 & 5 \\
\hline 4 & Basin Length (Lb) & 19.39 & 15.59 \\
\hline 4 & Stream Length $(\mathrm{Lu})$ & 270.33 & 192.45 \\
\hline 5 & Mean Stream Length (Lsm) & 4.47 & 4.62 \\
\hline 6 & weighted mean Stream length ratio (Luwm) & 2.45 & 2.85 \\
\hline \multirow[t]{2}{*}{7} & Bifurcation Ratio $(\mathrm{Rb})$ & 4.51 & 4.45 \\
\hline & Arial Aspect & & \\
\hline 8 & Drainage density (Dd) & 2.39 & 2.49 \\
\hline 9 & Drainage texture (Dt) & 5.31 & 4.58 \\
\hline 10 & Texture ratio $(\mathrm{T})$ & 4.12 & 3.55 \\
\hline 11 & Stream frequency $(\mathrm{Fs})$ & 3.88 & 4.37 \\
\hline 12 & Form Factor (Rf) & 0.30 & 0.32 \\
\hline 13 & Circularity Ratio (Rc) & 0.21 & 0.18 \\
\hline 14 & Elongation Ratio (Re) & 0.62 & 0.64 \\
\hline 14 & Length of Over Land Flow (Lg) & 0.21 & 0.20 \\
\hline 16 & Infiltration number (If) & 9.26 & 10.89 \\
\hline 17 & Constant channel maintenance & 0.42 & 0.40 \\
\hline 18 & Compactness coefficient $(\mathrm{Cc})$ & 2.19 & 2.36 \\
\hline \multirow[t]{2}{*}{19} & Drainage pattern & - & _- \\
\hline & Relief Aspects: & & \\
\hline 20 & High relief (Zmax) & 2459 & 2578 \\
\hline 21 & Low relief (Zmin) & 1690 & 1690 \\
\hline 22 & Basin Relief $(\mathrm{H})$ & 0.77 & 0.89 \\
\hline 23 & Relief Ratio (Rh) & 0.04 & 0.06 \\
\hline 24 & Relative relief (Rr) & 0.01 & 0.01 \\
\hline 25 & Ruggedness number(Rn) & 1.84 & 2.21 \\
\hline 26 & Dissection index (Dis) & 0.31 & 0.34 \\
\hline 27 & Basin Slope (Sb) & & \\
\hline
\end{tabular}




\section{Conclusions}

In the present study, efforts have made to evaluate morphometric parameters of Kito and Awetu sub-basins by using GIS and remote sensing techniques. Morphometric analysis was done for major parameters of three aspects namely, linear aspects, areal aspects, and relief aspects. A five order rivers drain both sub-basins and the proportion of the number of streams in each order indicates that the sub-basins are characterized by mountainous, highly dissected, steep slope region with mostly homogeneous geological materials. Comparatively Kito river sub-basin is highly dissected than Awetu sub-basin and Awetu sub-basin is more elongated than that of Kito sub-basin. The bifurcation ratio of the Kito and Awetu sub-basins are 4.51 and 4.45 respectively which indicates mountainous and steeply sloped region for both basins. The drainage density, stream frequency, and elongation ratio are $2.39,3.88$ and 0.62 respectively for Kito sub-basin and 2.49, 4.37 and 0.64 respectively for Awetu sub-basin. This shows that both sub-basins are elongated and characterized by flat hydrograph for longer duration and easier for flood management. The overall micrometric analysis indicated that the tributaries characterized by a steep slope and there is a quick concentration of runoff. But the main rivers are long and the sub-basins are elongated in shape. Slow and mild rising and falling limp hydrograph is expected at the mouth of the main rivers and easier for flood management. Relatively, Awetu River is easier for flood management than Kito River.

\section{Acknowledgements}

The authors thank the research and publication office of Jimma Institute of Technology for the opportunity given to the authors.

\section{References}

[1] Rao, N. K., Latha, S. P., Kumar, A. P. and Krishna, H. M., Morphometric analysis of Gostani river basin in Andhra Pradesh State, India using spatial information technology. International journal of geomatics and geosciences, 2010. 1(2): p. 179.

[2] Pingale, S. M., Chandra, H., Sharma, H. and Mishra, S. S., Morphometric analysis of Maun watershed in Tehri-Garhwal district of Uttarakhand using GIS. International Journal of Geomatics and Geosciences, 2012. 3(2): p. 373-387.

[3] Rai, P. K., Mohan, K., Mishra, S., Ahmad, A. and Mishra, V. N., A GIS-based approach in drainage morphometric analysis of Kanhar River Basin, India. Applied Water Science, 2014. 7(1): p. 217-232.

[4] Strahler, A. N., Part II. Quantitative geomorphology of drainage basins and channel networks. Handbook of Applied Hydrology: McGraw-Hill, New York, 1964: p. 4-39.

[5] Aravinda, P. and H. Balakrishna, Morphometric analysis of vrishabhavathi watershed using remote sensing and GIS. Int. J. Res. Eng. Tech, 2013. 2(8): p. 514-522.

[6] Panda, S. P., A Quantitative Analysis of Baitarani Drainage Basin (Odisha) Using Geographical Information System. Vistas in Geological Research (ISBN: 81-900907-0-4), Special Publication in Geology (14), 2016: p. 165-176.

[7] Rahaman, S. A., Ajeez, S. A., Aruchamy, S. \& Jegankumar, R., Prioritization of Sub Watershed Based on Morphometric Characteristics Using Fuzzy Analytical Hierarchy Process and Geographical Information System: A Study of Kallar Watershed, Tamil Nadu. Aquatic Procedia, 2015. 4: p. 1322-1330.

[8] YangchanJ, J. A., A. Tiwari, and A. Sood, Morphometric Analysis of Drainage Basin through GIS: A Case study of Sukhna Lake Watershed in Lower Shiwalik. India, IIJSER, 2015. 6(2).

[9] Dubey, S. K., D. Sharma, and N. Mundetia, Morphometric Analysis of the Banas River Basin Using the Geographical Information System, Rajasthan, India. Hydrology ISSN, 2015: p. $2330-7609$.

[10] Tribhuvan, P. and M. Sonar, Morphometric analysis of a Phulambri river drainage basin (Gp8 Watershed), Aurangabad district (Maharashtra) using geographical information system. International Journal of Advanced Remote Sensing and GIS, 2016: p. pp. 1813-1828.

[11] Farhan, Y. and O. Anaba, A remote sensing and GIS approach for prioritization of Wadi Shueib mini-watersheds (Central Jordan) based on morphometric and soil erosion susceptibility analysis. Journal of Geographic Information System, 2016. 8(01): p. 1.

[12] Faniran, A., The index of drainage intensity-A provisional new drainage factor. Australian Journal of Science, 1968. 31: p. 328-330.

[13] Horton, R. E., Erosional development of streams and their drainage basins; hydrophysical approach to quantitative morphology. Geological society of America bulletin, 1945. 56(3): p. 275-370.

[14] Melton, M. A., An analysis of the relations among elements of climate, surface properties, and geomorphology. 1957, Columbia Univ New York.

[15] Miller, V. C., Quantitative geomorphic study of drainage basin characteristics in the Clinch Mountain area, Virginia and Tennessee. Technical report (Columbia University. Department of Geology); no. 3, 1953.

[16] Schumm, S. A., Evolution of drainage systems and slopes in badlands at Perth Amboy, New Jersey. Geological society of America bulletin, 1956. 67(5): p. 597-646.

[17] Strahler, A. N., Statistical analysis in geomorphic research. The Journal of Geology, 1954. 62(1): p. 1-25.

[18] Strahler, A. N., Quantitative analysis of watershed geomorphology. Eos, Transactions American Geophysical Union, 1957. 38(6): p. 913-920.

[19] Farhan, Y., Morphometric Assessment of Wadi Wala Watershed, Southern Jordan Using ASTER (DEM) and GIS. Journal of Geographic Information System, 2017. 9(02): p. 158. 
[20] Fenta, A. A., Yasuda, H., Shimizu, K., Haregeweyn, N. and Woldearegay, K., Quantitative analysis and implications of drainage morphometry of the Agula watershed in the semi-arid northern Ethiopia. Applied Water Science, 2017. 7(7): p. 3825-3840.

[21] Pareta, K. and U. Pareta, Quantitative morphometric analysis of a watershed of Yamuna basin, India using ASTER (DEM) data and GIS. International journal of Geomatics and Geosciences, 2011. 2(1): p. 248.

[22] Rahaman, M. F., Jahan, C. S., Arefin, R. and Mazumder, Q. H., Morphometric Analysis of Major Watersheds in Barind Tract, Bangladesh: A Remote Sensing and GIS-Based Approach for Water Resource Management. Hydrology, 2018. 5(6): p. 86.

[23] Waikar, M. and A. P. Nilawar, Morphometric analysis of a drainage basin using geographical information system: a case study. International journal of multidisciplinary and current research, 2014. 2: p. 179-184.

[24] Gebre, T., Kibru, T., Tesfaye, S. and Taye, G., Analysis of watershed attributes for water resources management using GIS: The case of Chelekot micro-watershed, Tigray, Ethiopia. Journal of Geographic Information System, 2015. 7(02): p. 177 .

[25] Panhalkar, S., S. Mali, and C. Pawar, Morphometric analysis and watershed development prioritization of Hiranyakeshi Basin in Maharashtra, India. International Journal of Geomatics and Geosciences, 2012. 3(1): p. 525-534.

[26] Ratnam, K. N., Srivastava, Y., Rao, V. V., Amminedu, E. and Murthy, K., Check dam positioning by prioritization of micro-watersheds using SYI model and morphometric analysisâ€"remote sensing and GIS perspective. Journal of the Indian Society of Remote Sensing, 2005. 33(1): p. 25.

[27] Strahler, A. N., Dynamic basis of geomorphology. Geological Society of America Bulletin, 1952. 63(9): p. 923-938.

[28] Suma, B. and C. Srinivasa, A Study on Morphometric Parameter of a Watershed for Sustainable Water Conservation. International Journal of Civil Engineering and Technology, 2017. 8(9).

[29] Scheidegger, A. E., Hydrogeomorphology. Journal of Hydrology, 1973. 20(3): p. 193-215.

[30] Strahler, A. N., Hypsometric (area-altitude) analysis of erosional topography. Geological Society of America Bulletin, 1952. 63(11): p. 1117-1142.

[31] Strahler, A., Revisions of Horton's quantitative factors in erosional terrain. Trans. Am. Geophys. Union, 1953. 34: p. 345 .

[32] Sukristiyanti, S., R. Maria, and H. Lestiana. Watershed-based Morphometric Analysis: A Review. in IOP Conference Series: Earth and Environmental Science. 2017: IOP Publishing.

[33] Tolessa, G. A. and P. J. Rao, Watershed Development Prioritization of Tandava River Basin, Andhra Pradesh, India-GIS Approach. International Journal of Engineering Science Invention, 2013. 2(2): p. 12-20. 